\title{
Contingent Factors Affecting the Financial Performance of Manufacturing Companies: The Case of East Java, Indonesia
}

\author{
Hariyati* and BambangTjahjadi
}

\begin{abstract}
Manuscript type: Research paper.

Research aims: This study aims to examine how contextual variables which include innovation strategy, management accounting information system and internal business process performance affect the financial performance of manufacturing companies in East Java, Indonesia.

Design/ Methodology/ Approach: This study employs a quantitative approach to explain the relationship among the variables. The data of 135 managers were collected and then analysed through the partial least squares (PLS) approach.

Research findings: Results show that management accounting information system and business process performance partially mediate the innovation strategy-financial performance relationship.

Theoretical contributions/ Originality: This study expands on previous works by investigating the roles of management accounting information system and internal business process performance as mediating variables between innovation strategy and firm's financial performance.

Practitioner/ Policy implications: This study provides insights into how management accounting information system and internal business process performance impact innovation strategy and financial performance. The results imply that managers need to improve the design and implementation of their accounting system and their internal business process performance. This initiative can support
\end{abstract}

* Corresponding author: Hariyati is a Lecturer at the Accounting Department, Faculty of Economics, Universitas Negeri Surabaya, Indonesia. Email: hariyati@unesa.ac.id Bambang Tjahjadi is a Lecturer at the Accounting Department, Faculty of Economics and Business, Universitas Airlangga, Indonesia. Email: bambang.tjahjadi@feb.unair.ac.id 
the firm's innovation strategy which impacts on the firm's financial performance. The implications drawn from this study justify two things: (1) firms need to be more proactive in their product and process innovations so as to remain competitive in the global market; and (2) managers need to develop intangible assets such as a management accounting information system in the era of knowledge economy.

Research limitation: This study focusses on the manufacturing companies of the East Java Province of Indonesia therefore, generalisability of the findings may be restricted. Future studies need to incorporate larger and more diverse samples. This study did not consider the companies' business life cycle hence, the full impact of the firms' financial performance may not have been captured.

Keywords: Financial Performance, Innovation Strategy, Internal Business Process Performance, Management Accounting Information System.

JEL Classification: M41

\section{Introduction}

The prevalence of globalisation is widespread and impactful, particularly in the world of commerce and business. Organisations are facing more challenging competitions thus many are striving to look for a sustainable and competitive advantage that would help them to achieve better performance. Each organisation must formulate and execute the appropriate strategies to build its competitive advantage (Bowen, Moraga, \& Marathi, 2009; Mazanai \& Fatoki, 2011). In an effort to effectively execute the strategies chosen, organisations need to implement strategy-based performance management. Performance management should be multidimensional in nature, covering both financial and non-financial information. These two types of performance information must be aligned so that organisations are able to monitor, control, and achieve a comprehensive performance (e.g. Thrikawala, 2011; Arora \& Sharma, 2016).

A multi-dimensional performance management provides comprehensive performance information which is very crucial in supporting the execution of effective strategies. A single aspect of performance management is insufficient for the managers (Chen, Feldman, \& Tang, 2015). For example, to gain the lowest cost in operations, the management needs to have an excellent business process performance, in terms of operation 
management process and customer management process. An excellent business process performance, in turn, would also need the support of human capital management, information capital management, and the organisation's capital management. Performance management must provide all aspects of these critical information to managers at every level in the organisation. This study focusses on how excellent internal business process performance can improve firm's financial performance, the outcome of which is dependent on the business process performance. As suggested by Bhargava, Dubelaar and Ramaswami (1994) and Venkatraman and Ramunajam (1986), the firm's management needs to use integrated diverse measurements so as to accomplish excellent business process performance. When the firm's business process performance is excellent, the firm's financial performance also improves. The Balanced Scorecard (BSC) is a well-known example of a multidimensional model which is used to assess performance measurement and management. The BSC appears to be one of the "best practices" of performance management; it has been implemented in various types of organisations worldwide (Kaplan \& Norton, 1997). The BSC combines two important performance measurements such as non-financial and financial performance indicators within a causeeffect relationship. The BSC also consists of four perspectives: financial, customer, internal business process and learning and growth.

To determine the factors that would affect a firm's financial performance, this study adopted two approaches: the resource-based view and the contingency theory. According to the resource-based view, the key to improve a firm's performance is to look at the firm's internal characteristics (Barney, 1986; Afrifa \& Tauringana, 2015). Any difference noted in the firm's performance is explained primarily by the organisation's resources which should be valuable, rare and not easily imitated or substitutable by rivals. The contingency theory helps to explain how the design of an organisation would only be effective and universally applicable in certain environments when certain conditions are met (Otley, 1980; Uyar \& Kuzey, 2016). Since the condition and environment of each organisation is different, its design must also be unique. In this study, we highlight that innovative strategy, management accounting information system and internal business process management can act as contingent factors that affect firm's financial performance.

Prior empirical works (Roxas, Battisti, \& Deakins, 2014; Saunila, 2014) have illustrated that success in business is determined by innova- 
tion strategy. An innovation is a process that utilises resources (assets, skills, and capabilities) to accomplish something. Innovations are necessary in order to develop new products or services. Innovations are achieved by building new production systems and operations that address the needs of customers (Lopez-Valeiras, Gonzales-Sanchez, \& Gomez-Conde, 2015). The influence of innovation on performance indicators (such as customer satisfaction, productivity and technological competitiveness) has been demonstrated by Terziovski (2002). In his research, Terziovski (2002) suggested three types of innovation strategy: (1) integrated innovation strategy, (2) incremental innovation strategy, and (3) radical innovation strategy. He further asserted that incremental innovation strategy consists of product innovation and process innovation and that it is more appropriate to use incremental innovation strategy as an incentive for continuing an innovation. This is because it does not take much time to implement an innovation and innovation does not involve revolutionary changes which have higher risks of failure. In that regard, this study thus focusses on incremental innovation strategy.

The implementation of all types of innovation strategy however, requires a reliable management accounting information system. According to Chenhall and Morris (1986), reliable and accurate information comes from a reliable management accounting information system which carries the following criteria: broad scope, timeliness, aggregation and integration. Managerial performance is influenced by the interaction between management accounting information system and business strategy (Abdallah, 2014; Ali, Rahman, \& Ismail, 2012; Almajali, Masa'deh, \& Tarhini, 2016). The information provided by the management accounting information system plays a critical role in the managerial's decision making. Nonetheless, a reliable management accounting information system needs the readiness of information technology (Masa'deh, 2013; Masa'deh, Obeidat, \& Tarhini, 2016).

To advance the firm, its innovation strategy must be implemented together with its business process. The firm's internal business process is related to its operation management, customer management, innovation, as well as regulatory and social processes (Kaplan \& Norton, 1997; Erhemjamts, Li, \& Venkateswaran, 2013). In this regard, process innovation is associated with efficient production process, timely delivery to customers, and after-sales service. Excellent business process performance has an impact on cost efficiencies and product quality improvement. It accelerates asset utilisation, which in turn, 
has a positive impact on a firm's financial performance. To create value in these processes, the firm's accounting information system and business process performance need to play important roles. The effective implementation of a firm's innovation strategy can affect the firm's financial performance thus, it should be supported by a reliable management accounting information system and an excellent business process (Davis \& Cobb, 2010; Masa' deh, Shannak, Maqableh, \& Tarhini, 2017). Although these studies have demonstrated the importance of the management accounting information system and internal business process performance, little work has been done to explore this issue from the perspective of manufacturing companies in East-Java, Indonesia.

Attempting to fill in the gap, this study is also conducted based on a number of reasons. First, theories, concepts and practices developed in different contexts are not necessarily applicable to the context being studied. Moreover, a firm's resources and capabilities which include its management accounting information system, internal business processes and innovation strategy, are regarded as unique factors hence may vary from one context to another. These factors were thus used to explain the differences in the performance of manufacturing companies based in East-Java. Scholars (Lussier \& Pfeifer, 2001; Mazzucato \& Donovan, 2016; Mazzucato \& Penna, 2016) have argued that the determinants of a firm's performance need to be based on the context of research since performance may differ from one context to another, thus the relevance of the current study.

The manufacturing companies of the East Java Province of Indonesia contributes 10.04 per cent of Indonesia's export. The same area also contributes 20.85 per cent of the nation's GDP (Ministry of Industry, 2013). However, growth of the manufacturing industry in the East Java Province has been fluctuating since 2012. With competition coming from foreign manufacturers such as China, the phenomenon for the East Java Province may worsen. Therefore, it is necessary to conduct a study that can examine which contingent factors are likely to affect the financial performance of these manufacturing companies, in the midst of global competition.

This study contributes to the body of knowledge by providing additional evidence from the East Java Province that shows the mediating effect of management accounting information system and internal business process performance on innovation strategy-financial performance relationship. The findings may be useful to policy decision 
makers and managers who can use the outcome to improve the financial performance of the manufacturing sector of the East Java Province.

The rest of this paper is organised as follows. Section 2 presents the literature review and hypotheses development, while Section 3 explains the research methodology. Sections 4 reports on the findings and section 5 discusses the empirical results. Finally, section 6 provides the conclusion of the study.

\section{Literature Review and Hypotheses Development}

\subsection{Industry-Organisation (I/O) Paradigm versus Resource-Based Theory}

The issue on how an organisation pursues its competitive advantage and achieves above-average returns is still not settled and thus requires further research. The Industry-Organisation $(\mathrm{I} / \mathrm{O})$ paradigm states that external environment factors especially, industry factors, significantly affect firm's performance. The first empirical study supporting this paradigm was conducted by Schmalensee (1985) who revealed that industry factors affect firm's performance by approximately 20 per cent while in the case of McGahan and Porter (1997), industry factors affect firm's performance by 19 per cent. To achieve a competitive edge within the industry, an organisation needs to have a good strategy. However, the formulation of a good strategy may be influenced by external factors such as industry factors. These are usually beyond the control of the management as they are independent from the organisation (Morrison \& Teixeira 2004). In contrast, internal factors reveal how management preferences and company characteristics can influence the resolution of company issues or the expansion plans of company products, services or processes (Makhija, 2003). Unlike external factors that are out of the company's control, internal factors are unique to the company. They include the firm's resources and capabilities both of which can be controlled (Galbreath \& Galvin, 2008). Based on this, the current study focusses only on the internal aspects of the firms being investigated.

The resource-based view (RBV) states that a sustainable and competitive advantage depends on how a firm controls and properly utilises its specific internal resources. This theory focusses on the firm's resources and capabilities that would determine the performance of the firm. Resources that comprise assets, skills, and capabilities will determine the empowerment process of the firm towards the creation of its competitiveness. Teece, Pisano, \& Shuen (1997) stated that a competitive advantage depends on the resources owned by the firm. 
This is expanded by Barney (1986) who suggested that resources can be generally defined as assets, organisational processes, firm attributes, information, or knowledge, all of which are controlled by a company and which can be used to develop and implement the company's business strategies. Barney, Wright, \& Ketchen (2001) explained that a company is a collection of resources, competencies and capabilities. The difference between companies can be noted by their respective resources, competencies and capabilities, all of which can determine the firm's competitive advantage. The firm's management accounting information system and business processes are therefore, employed in this study as critical resources that would help firms to create a superior financial performance.

\subsection{The Contingency Theory}

Otley (1980) states that no single organisational design can be effectively applied universally under any condition or in any context. In this regard, the contingency approach explains why the accounting system can differ from one condition to another. Otley's (1980) findings suggested that three concepts influence the effectiveness of an accounting system namely: (1) technology, (2) organisational structure, and (3) environment. Harash, Al-Timimi, \& Alsaadi (2014) has suggested that the contingency approach is appropriate for analysing and designing the control system, particularly in the field of management accounting system.

Researchers in the field of management accounting such as Chong and Chong (1997) have conducted studies to determine the relationship among the contextual variables (or contingent factors) such as environment uncertainty, tasks uncertainty, structure and organisational culture, strategy uncertainty, and management accounting information system design. The contingency approach is used to explain how the contingent factors could affect the competitive advantage or perfor-mance of a firm. Likewise, this study also employed the contextual or contingent variables of innovation strategy, management accounting in-formation system, and internal business process performance as factors that would enable a firm to achieve excellent financial performance.

\subsection{Theoretical Framework and Hypotheses Development}

A research model is developed based on the theoretical reviews covered. This is presented in Figure 1. The model illustrates that financial 


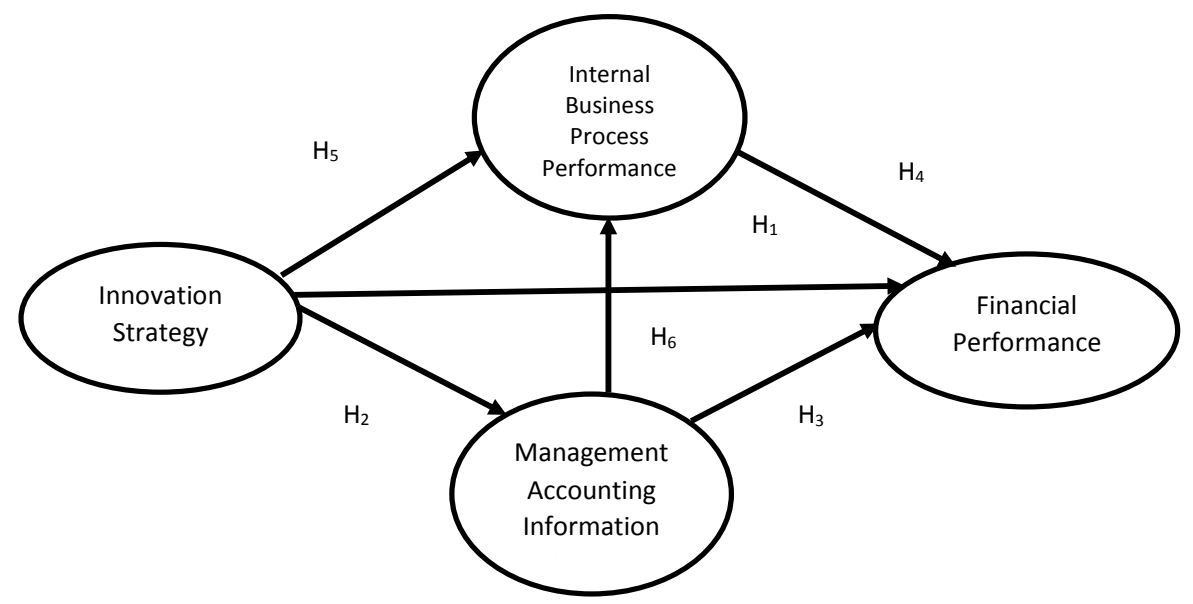

Figure 1: Research Model

performance is affected by innovation strategy which is mediated by the management accounting information system and the internal business process performance.

\subsubsection{The Relationship between Innovation Strategy and Financial Performance}

Financial performance is a critical aspect of a firm because it is the output of the management's efforts in utilising the firm's resources to maximise shareholders' value. Financial performance reports can indicate whether a firm's strategy contributes to the bottom-line improvement or not. Kaplan (2009) stated that the financial performance of a firm can be improved in two ways i.e., through growth strategy and productivity strategy. Firms are able to generate profit by improving productivity through innovation - product innovation and process innovation. Improvements in productivity can be achieved by: (1) reducing direct and indirect expenses or by using financial and physical assets more efficiently, and (2) reducing the working and fixed capital needed to support a given business level. The linkage strategy in the financial perspective arises when firms achieve a balance between growth and productivity. Three main indicators are used to measure financial performance namely: (1) revenue growth, (2) cost reduction or cost savings and increased asset utilisation and (3) increased customer value. 
Innovation is defined as a process created in an organisation to look at how skills and resources are utilised for the purpose of developing new products and or services or to establish new production systems and operations so as to address the needs of customers (Gao, Hsu, $\& \mathrm{Li}, 2018)$. Innovation is necessary for creating value for example, in penetrating new markets, in retaining existing market shares and in improving a competitive advantage. Innovation is an important element of a business strategy. Through innovation, organisations are better assured in winning the global competition. Innovation has also become the main focus of the academic and industrial research platform. Extensive studies (e.g. Hitt, Ireland, Camp, \& Sexton, 2001; Kuratko, Ireland, Covin, \& Hoprnsby, 2005) have acknowledged the importance of innovation in achieving a sustainable competitive advantage in the global competition. The goal of innovation is not only to reduce costs but also to help firms to improve the quality of their products and services offered. This is important in the globalisation era as products' lifecycle becomes shorter due to customers who have developed a variety of needs and demands. In sum, innovation is crucial for developing new products and services, for creating organisational models and for marketing techniques.

Early research by Evangelista, Sandven, Sirilli, and Smith (1998) indicated that companies need to be more innovative in order to remain competitive. Global competition is not only forcing firms to enhance product innovation, but also to enhance their technological capabilities in producing products or services at cheaper costs. Firms therefore, need to manipulate the structure and organisation of their work process, improve their core competencies and develop new structures in the effort to respond to new market conditions and customer demands (Ulusoy, Özgür, Bilgiç, Kaylan, \& Payzın, 2001). The success or failure of a firm in achieving excellent performance is determined by its innovation (Hamel, 1999). Based on this, the first hypothesis developed is as follows:

$\mathrm{H}_{1}$ : Innovation strategy positively affects financial performance.

\subsubsection{The Relationship between Innovation Strategy and Management Accounting Information System}

A unique way to achieve excellent performance is to develop innovation strategy. Innovation strategies promote creative ideas and encourage risk taking to experiment with new ways to various firms' activities. A 
firm that embark on innovative strategy is more likely to seek for new and novel information during information generation, so that they can respond well to potential market opportunities. Hence, this strategy may affect the design of the management accounting information systems in a way that it needs to provide relevant, timely, accurate and complete information. The development of modern performance management, which incorporate innovation strategy proves that characteristics of the management accounting information system such as timeliness, aggregation and integration are useful for managers particularly when it covers a broader scope. Managers depend on the management accounting information system to be able to effectively execute the innovation strategy. The more reliable the accounting information generated, the better the decisions taken by the organisation, and the higher the opportunity for the firm to remain competitive. A company or organisation that implements innovation strategy will be exposing a broad environmental domain hence, it would require larger amounts of information, which may affect the development of management accounting information system. Based on the argument, the second hypothesis developed is as follows:

$\mathrm{H}_{2}$ : Innovation strategy positively affects management accounting information system.

\subsubsection{The Relationship between Management Accounting Information System and Financial Performance}

The management accounting information, as a product of the management accounting system, plays a critical role in helping the management to predict possible consequences of the various alternative strategies that can be performed in a variety of activities such as planning, controlling and decision making. Information system is effective when it supports good management decisions (Sprinkle, 2003; Nguyen, Mia, Winata, \& Chong (2017). The better the system, the higher the quality of the information generated by the system. The quality of the information will improve the quality of the decision to be taken and ultimately, improve the performance of the company (Gerloff, Muir, \& Bodensteiner, 1991). In his work, Nazaruddin (1998) suggested that management accounting information system is only reliable if it can improve managerial performance. Chong and Chong (1997) asserted that the availability of the broad scope management accounting 
information is an important antecedent variable in improving firm's performance. A study by Rawasdeh and Al-namlah (2017) in Saudi Arabia revealed the importance of adopting electronic data interchange in small and medium enterprises so as to improve performance and to remain competitive. Management accounting information system is also expected to positively affect the financial performance through providing relevant, accurate and timely information. Based on the argument, the third hypothesis developed is as follows:

$\mathrm{H}_{3}$ : Management accounting information system positively affects financial performance.

\subsubsection{The Relationship between Internal Business Performance and Financial Performance}

As previously described, firms must execute their innovative strategies effectively so as to ensure good financial results. Strategies must be executed by conducting strategic activities or processes. Firms must manage their internal business processes in order to achieve excellent operations management, customer management, innovation management, and regulatory management. To achieve excellent internal business process performance, firms must be supported by skillful human resources, a reliable information system as well as a solid organisation capital. Kaplan and Norton (2001) classified internal business processes into four groups. The first group involves the operations management processes. This refers to activities in dealing with suppliers, producing products, distributing products to customers, and managing risks. The second involves customer management processes. This refers to how the firms broaden and deepen relationships with targeted customers. Customer management involves four factors such as the selection of targeted customers, the acquisition of targeted customers, the retention of customers, and the expansion of customers. The third group is the innovation management processes which involve four steps: identifying opportunities for new goods and services, managing a portfolio for research and development, designing and developing new products and putting the new products on the market. The fourth group is the regulatory and social processes which refer to activities that continually help firms to have the right to operate in a specific community, to enjoy safety and health and to promote employee practices as well as community development. Good 
internal business performance can lead to a healthy organisation thereby enabling it to achieve its objectives. In conclusion, internal business process performance affects firm's financial performance. Based on the argument, the fourth hypothesis developed is as follows:

$\mathrm{H}_{4}$ : Internal business process performance positively affects financial performance.

\subsubsection{The Relationship between Innovation Strategy and Internal Business Process Performance}

Innovation strategy is a unique way for a firm to reach its targeted performance. The management formulates and implements this innovation strategy to achieve excellent internal business performance. According to Verhoeven and Johnson (2017), firms need to have more dynamic views on their business model innovation. Doing so helps them to enhance the dynamic analysis of their strategic development and business model innovation processes. Chuan and Lin's (2017) empirical study of financial service firms in Taiwan revealed that innovation strategy emphasises on service innovation orientations which in turn, examine the information-value offerings that can elevate the firms' internal business process performance and their customer relationship performance. Gao et al. (2018) provided evidence which suggests that the investment horizon is key to explaining the different innovation strategies used by the public and private firms in improving their business performance and in remaining competitive. Based on the argument, the fifth hypothesis developed is as follows:

$\mathrm{H}_{5}$ : Innovation strategy positively affects internal business process performance.

\subsubsection{The Relationship between Management Accounting Information System and Internal Business Process Performance}

Kaplan (2009) stated that information capital, including the management accounting information system, has a strategic role in building a company's competitive advantage in the era of knowledge-based economy. Using strategy maps, Kaplan and Norton's (2001) results showed that the firm's learning and growth perspective have direct linkage with the firm's internal business processes. The more excellent the information capital, the more significant the internal business pro- 
cess performance. This justifies the sixth hypothesis which is developed as follows:

$\mathrm{H}_{6}$ : Management accounting information system positively affects internal business process performance.

\subsubsection{Mediating Effect of Management Accounting Information System on the Relationship between Innovation Strategy and Financial Performance}

An innovation strategy that is adopted by a firm impacts the information that is needed to effectively implement the strategy. Bromwich (1990) argues that management accounting information system can help managers to face challenges in a competitive market. Management accounting information system focusses on generating information to create value, to assist managers in monitoring the performance, and to predict possible consequences of various alternative actions that can be performed on a variety of activities. As stated by Gerloff et al. (1991), the information that is available in a firm is considered to be effective if it can support the users or decision-makers. The link between information needed and the decision makers is that good information will increase the quality of the decision; ultimately, this improves the firm's financial performance. Every strategy taken by the firm, including innovation strategy, impacts on the characteristics of the information system including management accounting information system. As stated by Chenhall and Morris (1986), reliable accounting information must have the characteristics of broad scope, aggregation, timeliness, and integration. In conclusion, the implementation of an innovation strategy determines the need for a reliable management accounting information system, which in turn, affects the firm's financial performance. Based on the argument, the seventh hypothesis developed is as follows:

$\mathrm{H}_{7}$ : Management accounting information system mediates the relationship between innovation strategy and financial performance.

\subsubsection{Mediating Effects of Internal Business Process Performance on Innovation Strategy-Financial Performance Relationship}

The innovation strategy implemented will affect the firm's internal business process performance such as innovation, operation, and aftersales service processes. Innovation processes refer to the process of creating products and services that meet the needs of customers; it 
increases the use of technologies in new product development efforts. Operation processes are associated with efficient production process, timely delivery to customers, and after-sales service. Therefore, an efficient internal business process performance will affect customer relationship performance, increase market share, maintain existing customers, increase new customers, improve customer satisfaction as well as increase customers' value. Terziovski (2002) in his study provided evidence to suggest that innovation strategy affects internal business process performance, customer relationship performance, and financial performance. Based on the argument, the eighth hypothesis developed is as follows:

$\mathrm{H}_{8}$ : Internal business process performance mediates the relationship between innovation strategy and financial performance.

\subsubsection{Mediating Effects of Management Accounting Information System and Internal Business Process Performance on Innovation Strategy- \\ Financial Performance Relationship}

Each strategy performed by the firm leads to different designs of the information system. Therefore, innovation strategy also influences the design of the management accounting information system. A good management accounting information system tends to enhance the internal business process performance, helping the firm to achieve better operation management processes (supply chain, production, distribution, risk management), better customer management processes (customer selection, acquisition, retention, growth), better innovation management processes, and better social and regulatory management processes. In this regard, it is evident that an excellent internal business process will improve a firm's financial performance hence, accelerating revenue growth and cost efficiencies. Based on the argument, the ninth hypothesis developed is as follows:

$\mathrm{H}_{9}$ : Management accounting information system and internal business process performance mediate the relationship between innovation strategy and financial performance.

\section{Research Methodology}

To operationalise the construct of this study, the operational definitions and measures are developed as follows. Financial performance is defined as the perception of the respondents towards the current 
financial condition of the strategic business units as compared to previous years. To measure financial performance, we used the financial indicators developed by Kaplan and Norton (2001) namely: improved cost structure, increased asset utilisation, expanded revenue opportunities and enhanced customer value.

Innovation strategy is a means used by an entity to compete in its industry in a sustainable manner (Terziovski, 2002). In this study, innovation strategy is defined as the perception of the respondents towards their unique ways in achieving a sustainable and competitive advantage and excellent performance. To measure innovation strategy, we used two indicators developed by Terziovski (2002) namely: product innovation and process innovation.

Management accounting information system is defined as the perception of the respondents towards the design of the accounting system which generates the management accounting information needed by management so as to make better decisions, in its effort to support the formulation and execution of innovation strategy. To measure management accounting information system, we adopt the instrument developed by Chenhall and Morris (1986) which included four aspects: broadscope, aggregation, integration and timeliness.

Internal business process performance is defined as the perception of the respondents towards the performance of the value chain or the strategic activities that were conducted in strategic business units (SBUs) so as to support customer satisfaction and/or productivity strategy which increases financial performance. To measure internal business process performance, we use four indicators developed by Kaplan and Norton (2001) namely: operation management processes, customer management processes, innovation management processes and regulatory and social management processes. The measurement scales were translated into the Indonesian language and a back-toback translation was applied to ensure a high level of consistency. The items of measurement are presented in Appendix A. Respondents were asked to rate their perceptions on a 5-point Likert scale, ranging from 1 (strongly disagree) to 5 (strongly agree).

\subsection{Data Collection}

This study is designed as a causal study (Cooper \& Emory, 1995) using data collected from a questionnaire survey. The unit of analysis is strategic business unit and the respondents recruited comprise 
managers of these strategic business units in manufacturing companies located in the East Java Province of Indonesia. The sampling frame was drawn from the list of manufacturing firms located in the province and registered with the Ministry of Industry, the Republic of Indonesia as of 2016. The entire population was 398 and so a total of 398 questionnaires were distributed using several channels including emails, snail mails, and personal visits. However, our study drew only 34 per cent response rate, resulting in only 135 respondents who participated. Based on the Law Number 20 Year 2008 report which describes Micro, Small, Medium, and Large Enterprises, it was observed that many of these companies (79 per cent) were manufacturing companies that were also mainly medium enterprises, as illustrated in Table 1. Most (74 per cent) have been in the business between six to 15 years and the type of company varies in terms of products produced.

Table 1: Profile of Respondents

\begin{tabular}{llcr}
\hline $\begin{array}{l}\text { Demographic } \\
\text { Variables }\end{array}$ & Category & $\begin{array}{c}\text { Frequency } \\
(\mathrm{n}=135)\end{array}$ & $\begin{array}{r}\text { Percentage } \\
(\%)\end{array}$ \\
\hline Firm Size & Small & 0 & 0 \\
& Medium & 107 & 79 \\
& Large & 28 & 21 \\
\hline Age of Firms & $0-5$ & 25 & 19 \\
& $6-10$ & 40 & 30 \\
& $11-15$ & 60 & 44 \\
Type of Firms & 10 & 7 \\
& Between 15 to 20 & 6 & 4.44 \\
& Jewelry / Gem & 12 & 8.88 \\
& Fat \& Animal / Vegetable oil & 18 & 13.33 \\
& Wood, Articles of Wood & 11 & 8.15 \\
& Fish and Shrimp & 17 & 12.59 \\
& Paperboard & 16 & 11.85 \\
& Organic Chemicals & 11 & 8.16 \\
& Copper & 11 & 8.16 \\
& Meat and Processed Fish & 17 & 12.59 \\
& Furniture, Home Lighting & 16 & 11.85 \\
\hline
\end{tabular}




\section{Data Analysis and Findings}

\subsection{Measurement Model Analysis}

Partial Least Squares (PLS) is used to examine the hypothesised model. Prior to the structural model analysis, a measurement model analysis is first performed to determine the validity and reliability of the model used. This is done by examining the convergent validity and discriminant validity. The former is assessed through factor loadings, average variance extracted (AVE) and composite reliability (Hair, Sarstedt, Hopkins, \& Kuppelwieser, 2014). The latter is assessed by comparing the squared correlations between the constructs and the AVE for the particular construct (Fornell \& Larcker, 1981).

Table 2 highlights loadings of all items which exceeded the threshold value of 0.5 (Bagozzi, Yi, \& Phillips, 1991). The composite reliability values ranged between 0.748 to 0.93 , exceeding the recommended value of 0.7 (Hair et al. 2014). Additionally, the AVE values are in the range of 0.539 to 0.768 , which exceeded the recommended value of 0.5 (Hair et al., 2014).

Table 2: Convergent Validity Analysis

\begin{tabular}{llccc}
\hline Constructs & Items & $\begin{array}{c}\text { Factor } \\
\text { Loadings }\end{array}$ & $\begin{array}{c}\text { Composite } \\
\text { Reliability }\end{array}$ & AVE \\
\hline Innovation Strategy & STR 1 & 0.92 & 0.917 & 0.847 \\
& STR 2 & 0.92 & & \\
\hline Management Accounting & MAIS 1 & 0.771 & 0.748 & 0.539 \\
Information System & MAIS 2 & 0.552 & & \\
& MAIS 3 & 0.650 & & \\
& MAIS 4 & 0.809 & & 0.737 \\
Internal Business Process & IBP1 & 0.837 & 0.918 & \\
Performance & IBP2 & 0.844 & & 0.768 \\
& IBP3 & 0.897 & & \\
\hline Financial Performance & IBP4 & 0.855 & & \\
& FP1 & 0.836 & 0.930 & \\
& FP2 & 0.855 & & \\
& FP3 & 0.917 & & \\
& FP4 & 0.895 & & \\
\hline
\end{tabular}


Table 3 depicts the results of the discriminant validity. It is deemed to exist only if the value of the AVE for a particular construct is higher than its correlation with other constructs. As can be noted in Table 3, all the constructs appear to have a substantially higher AVE as compared to the correlation with other constructs, indicating discriminant validity.

Table 3: Discriminant Validity Analysis

\begin{tabular}{lcccccc}
\hline & M & SD & STR & MAIS & IBP & FP \\
\hline Innovation Strategy (STR) & 4.33 & 0.66 & $\mathbf{0 . 7 7}$ & & & \\
$\begin{array}{l}\text { Management Accounting } \\
\quad \text { Information System (MAIS) }\end{array}$ & 4.13 & 0.55 & 0.42 & $\mathbf{0 . 7 9}$ & & \\
$\begin{array}{l}\text { Internal Business Process } \\
\quad \text { Performance (IBP) }\end{array}$ & 4.38 & 0.64 & 0.57 & 0.51 & $\mathbf{0 . 7 3}$ & \\
$\quad$ Financial Performance (FP) & 4.31 & 0.63 & 0.52 & 0.25 & 0.32 & $\mathbf{0 . 7 1}$ \\
\hline
\end{tabular}

Note: The numbers in bold in the diagonal row are square roots of the $\mathrm{AVE}, \mathrm{SD}=$ Standard Deviation, $\mathrm{M}=$ Mean.

\subsection{Structural Model Analysis}

Assuming that the measurement model satisfies the validity and reliability assessment, this study proceeded with the structural model analysis. The predictive accuracy of the model is evaluated in terms of the portion of variance explained. The results reveal that the model is capable of explaining 52.3 per cent of the variance in financial performance. The significance of the direct effect as specified by the research model is evaluated (Table 4). The results reveal that the effects of innovation strategy on financial performance $(\beta=0.73, p<0.001)$ and management accounting information system $(\beta=0.481, p<0.001)$ are positive and significant. Hence, $\mathrm{H}_{1}$ and $\mathrm{H}_{2}$ are supported. Additionally, this study also demonstrates that the effect of management accounting information system on financial performance is significantly positive $(\beta=0.548, p<0.001)$ thereby, supporting $\mathrm{H}_{3}$. The relationship between internal business performance and financial performance $\left(\mathrm{H}_{4}\right)$ is also supported $(\beta=0.485, p<0.001)$. This study also reports that the effect of innovation strategy on internal business performance is significantly positive $(\beta=0.687, p<0.001)$ hence, supporting $\mathrm{H}_{5}$. Finally, this study also reveals that the effect of management accounting information system on internal business process performance is significantly positive $(\beta=0.550$, $p<0.001)$, thereby, supporting $\mathrm{H}_{6}$. 
Table 4: Direct Effect

\begin{tabular}{clclrc}
\hline Hypothesis & \multicolumn{1}{c}{ Path } & \multicolumn{1}{c}{$\beta$} & Decision & t-value & Standard Error \\
\hline $\mathrm{H}_{1}$ & IS $\rightarrow$ FP & $0.730^{* * *}$ & Supported & 11.63 & 0.08 \\
$\mathrm{H}_{2}$ & IS $\rightarrow$ MAIS & $0.481^{* * *}$ & Supported & 2.87 & 0.00 \\
$\mathrm{H}_{3}$ & MAIS $\rightarrow$ FP & $0.548^{* * *}$ & Supported & 3.04 & 0.07 \\
$\mathrm{H}_{4}$ & IBP $\rightarrow$ FP & $0.485^{* * *}$ & Supported & 2.99 & 0.16 \\
$\mathrm{H}_{5}$ & IS $\rightarrow$ IBP & $0.687^{* * *}$ & Supported & 11.28 & 0.06 \\
$\mathrm{H}_{6}$ & MAIS $\rightarrow$ IBP & $0.550^{* * *}$ & Supported & 10.29 & 0.07 \\
\hline
\end{tabular}

Note: IS = Innovation Strategy, MAIS = Management Accounting Information System, $\mathrm{IBP}=$ Internal Business Process Performance, FP = Financial Performance, ${ }^{* * *} p<0.001$.

\subsection{Indirect Effect}

Baron and Kenny's (1986) procedure is applied in this study to analyse the mediating effect of management accounting information system and internal business process performance on financial performance. Four conditions must be satisfied to establish a mediating effect. First, a direct link between the independent and dependent variable must be established; second, the independent variable must be associated to the mediating variable; third, the mediator must be significantly related to the dependent variable when both the mediating variables are predictors of the dependent variable; and fourth, the relationship between the independent and dependent variable must be significantly reduced when the mediator is added.

As indicated in Appendix B, innovation strategy has a significant relationship with management accounting information system $\left(\mathrm{H}_{2}\right)$ and financial performance $\left(\mathrm{H}_{1}\right)$. This satisfies the first and second requirements. The mediator variable of management accounting information system has a positively significant relationship with financial performance $\left(\mathrm{H}_{3}\right)$. This satisfies the third requirement. The fourth step is to incorporate the mediator into the model. It is found that including management accounting information system into the model reduces the effect. The $\beta$ value dropped from 0.73 to 0.56 , indicating the existence of a mediator. Thus, $\mathrm{H}_{7}$ is supported.

This study also examines the impact of internal business process performance as a mediator between innovation strategy and financial performance. As indicated in Table 4, innovation strategy has a 
positive effect on financial performance $\left(\mathrm{H}_{1}\right)$ hence, satisfying the first condition. Innovation strategy has a positive and significant relationship with internal business process performance $\left(\mathrm{H}_{5}\right)$ thus, satisfying the second condition. Internal business process performance has a positive relationship with financial performance $\left(\mathrm{H}_{4}\right)$ therefore, satisfying the third condition. The fourth step is to incorporate the mediator into the model. It is found that by including internal business process performance into the model, the effect has been reduced, as the $\beta$ value dropped from 0.73 to 0.56 , thereby, indicating the existence of a mediator. Thus, $\mathrm{H}_{8}$ is supported.

This study also revealed the significant impact of management accounting information system on internal business process performance $\left(\mathrm{H}_{6}\right)$. In this regard, it supports $\mathrm{H}_{9}$, showing the innovation strategymanagement accounting information system-internal business process performance-financial performance relationship.

\section{Discussion}

This study provides empirical evidence that support the contingency theory. The results indicate that the financial performance of the manufacturing firms in the East Java Province is affected by contingent factors such as innovation strategy, management accounting information system, and internal business process performance. This outcome is in line with extensive previous studies (Evangelista et al., 1998; Hamel, 1999; Hitt et al., 2001; Ulusoy et al., 2001; Terziovski, 2002; Kuratko et al., 2005; Kaplan, 2009). Recently, there was an extensive movement made by the government of Indonesia to boost innovation-based industry in the East Java Province. The government encouraged the manufacturing companies to collaborate with universities as one measurement to help these companies to improve their competitive edge and performance in response to global competition, especially those coming from China, in the era of the ASEAN Economic Community (AEC). This movement reflects the government's recognition of innovation strategy as a critical factor for achieving good financial performance in view of global competition.

The findings of this study support the outcome noted by Chenhall and Morris (1986) where it was shown that strategy affects the design of the management accounting information system. In the context of this study, the respondents were managers of medium and large manufacturing companies which used extensive information 
communication technology. As mentioned earlier, modern performance management requires both the financial and non-financial information so as to be able to effectively formulate and execute the strategy. Chenhall and Morris (1986) indicate that management accounting information system is useful for managers when it covers broad scope, timeliness, aggregation and integration. The outcomes gathered from the current study also explain why management accounting information system is required by the managers of the manufacturing companies in the East Java Province. Nonetheless, different strategies require different designs in management accounting information system thus companies need to be more innovative in their approach.

The outcomes drawn from the current study also support the findings of previous studies conducted by Gerloff et al. (1991), Chong and Chong (1997) and Nazarruddin (1998) whose studies have highlighted the relationship between information needs of decisionmaking and performance. Managers of companies in the East Java Province realise that they are entering a knowledge-based competition ground where innovation and the use of information communication technology are crucial for achieving excellent financial performance. The difficulty of competing against cheap products from China has driven these managers to innovate and they would require strong strategic information in order to make good decisions. In this regard, the managers perceive that they would achieve excellent financial results if they have the strategic and useful information that is generated by the management accounting information system.

The results of the current study also endorse the study of Kaplan and Norton (2001) who stated that excellent financial performance is the result of excellent internal business process performance which comprises operation management, customer management, innovation management and regulatory management processes. Due to the global competition offered by China and other ASEAN countries, there is no choice for the managers in the East Java Province but to find better ways of improving their internal processes. These processes should also include aggressive marketing and cost reduction schemes so that they can still remain competitive. The current study provides empirical evidences which show that the managers of the manufacturing companies in the East Java Province have the perception that excellent internal business process performance will directly affect their financial performance (revenue growth and cost efficiencies). 
The results of this study also support the outcomes of previous studies (Lichtenthaler, Hoegl, \& Muethel, 2011; Dorweiler \& Yakhou, 2005) which show the important role innovation has on internal business process excellence. Innovation is a source enhancing added-values and profits hence, vital for improving performance and competitiveness. The findings of this study also endorse the observations of Chenhall and Morris (1986) and Kaplan (2009) who stated that management accounting information system has a strategic role in building a firm's competitive advantage in the era of knowledge-based economy. In the context of this study, the managers of the manufacturing companies in the East Java Province use massive computerised-based information system to generate more accurate information that can support better decision making. The better the information they get, the better the internal business process performance they achieve (operation management processes and customer management processes). This justifies why the managers of the manufacturing companies in the East Java Province perceive that management accounting information system affects internal business process performance.

This study provides empirical support which shows the mediating roles of management accounting information system and internal business process performance on the relationship between innovation strategy and financial performance. This study also confirm previous studies conducted by Gordon and Narayanan (1984), Chenhall and Morris (1986), Gerloff et al. (1991), Chong and Chong (1997) with regards to the importance of management accounting information system in relation to organisational performance. In addition, findings of this study also support Kaplan and Norton $(1997,2001)$ who stated that strategy must be translated into internal business processes so as to create excellent customer relationship performance and financial performance. The internal business processes include operations management processes, customer management processes, innovation management as well as regulatory and social processes.

Based on the above discussions, this study thus concludes that strategy affects the design of management accounting information system; management accounting information system influences internal business performance and internal business performance affects financial performance. The path tests also reveal that the managers are aware that they should align the design of their management accounting information system to innovation strategy. The better the quality of their management accounting information system, the better it will support 
their internal business processes. Further, the higher the internal business performance, the better it supports financial performance. The findings of this study also confirm the results of other studies conducted by Clemons and Row (1991), Mahmood and Mann (1993), Kettinger, Grover, Guha and Segars (1994), all of whom have concluded that management accounting information system offers a big opportunity for firms to improve their coordination and control. Alternatively, the findings of this study can be used by the respective companies to innovate and to gain a competitive advantage in the world market.

\section{Conclusion}

From the discussions noted above, several conclusions can be deduced. First, innovation strategy significantly affects financial performance. Second, management accounting information system and internal business process performance partially mediate the relationship between innovation strategy and financial performance. Third, management accounting information system mediates the relationship between innovation strategy and business process performance. Fourth, internal business process performance mediates the relationship between management accounting information system and financial performance.

This study has important future implications on manufacturing companies in the East Java Province, Indonesia. The outcome suggests that manufacturing firms in the East Java Province need to be more innovative, both in product innovation and process innovation so as to remain competitive in the marketplace. The findings also imply that these manufacturing companies need to focus on the development of intangible assets, among others, its management accounting information system. This manifestation is very crucial because without a reliable information system, innovative strategy cannot be executed properly, and so, it cannot drive excellent internal business process performance. Moreover, bad internal process performance may result in unhappy customers causing firms to lose their customer base. All these outcomes can affect the companies' financial performance badly. In conclusion, this research has offered an adequate explanation on how contextual variables or contingent factors can affect the financial performance of manufacturing firms in the East Java Province. The results of this study have important implications on the management of manufacturing firms in the East Java Province. Clearly, the management must improve its awareness of products as well as its process of innovation strategy in 
order to achieve excellent performance. Furthermore, the management must increase its concerns in the development of its management accounting information system because the system plays a strategic role in helping managers to make good decisions and to improve internal business performance.

This study has several limitations, including: (1) it does not consider product life cycle, and (2) it is limited to the manufacturing industry in the East Java Province, Indonesia only. Therefore, the results cannot be generalised. Future research should consider using other contextual variables such as human capital, organisation capital, and customer relationship performance as new contingent factors in the model.

\section{References}

Abdallah, A.A.J. (2014). The impact of using accounting information systems on the quality of financial statements submitted to the income and sales tax department in Jordan. European Scientific Journal, 9(10), 41-48.

Afrifa, G.A., \& Tauringana, V. (2015). Corporate governance and performance of UK listed small and medium enterprises. Corporate Governance, 15(5), 719-733. http://dx.doi.org/10.1108/CG-03-2015-0029

Ali, A., Rahman, M.S.A., \& Ismail, W.N.S.W. (2012). Predicting continuance intention to use accounting information systems among SMEs in Terengganu, Malaysia. International Journal of Economics and Management, 6(2), 295-320. http://dx.doi.org/10.4172/2162-6359.1000466

Almajali, D.A., Masa'deh, R., \& Tarhini, A. (2016). Antecedents of ERP systems implementation success: A study on Jordanian healthcare sector. Journal of Enterprise Information Management, 29(4), 549-565. http://dx.doi.org/ 10.1108/JEIM-03-2015-0024

Arora, A., \& Sharma, C. (2016). Corporate governance and firm performance in developing countries: Evidence from India. Corporate Governance, 16(2), 420-436. http://dx.doi.org/10.1108/CG-01-2016-0018

Bagozzi, R.P., Yi, Y., \& Phillips, L.W. (1991). Assessing construct validity in organizational research. Administrative Science Quarterly, 36(3), 421-458. http://dx.doi.org/10.2307/2393203

Barney, J., Wright, M., \& Ketchen, D.J. (2001). The resource-based view of the firm: Ten years after 1991. Journal of Management, 27(6), 625-641. http:// dx.doi.org/10.1177/014920630102700601

Barney, J.B. (1986). Strategic factors markets: Expectations, luck, and business strategy. Management Science, 32(10), 1231-1241. http://dx.doi.org/ 10.1287/mnsc.32.10.1231

Baron, R.M., \& Kenny, D.A. (1986). The moderator-mediator variable distinction in social psychological research: Conceptual, strategic, and statistical considerations. Journal of Personality and Social Psychology, 51(6), 1173-1182. 
Bhargava, M., Dubelaar, C., \& Ramaswami, S. (1994). Reconciling diverse measures of performance: A conceptual framework and test of a methodology. Journal of Business Research, 31(2-3), 235-246. http://dx.doi. org/10.1016/0148-2963(94)90087-6

Bowen, M., Moraga, M., \& Marathi, M. (2009). Management of business challenges among small and micro enterprises in Nairobi-Kenya. KCA Journal of Business Management, 2(1), 16-31. http://dx.doi.org/10.4314/ kjbm.v2i1.44408

Bromwich, M. (1990). The case for strategic management accounting: The role of accounting information for strategy in competitive markets. Accounting, Organizations and Society, 15(1-2), 27-46. http://dx.doi.org/10.1016/03613682(90)90011-I

Chen, L., Feldmann, A., \& Tang, O. (2015). The relationship between disclosure of corporate social performance and financial performance: Evidence from GRI reports in manufacturing industry. International Journal of Production Economics, 170, 445-456. http:/ /dx.doi.org/10.1016/j.ijpe.2015.04.004

Chenhall, R.H., \& Morris, D. (1986). The impact of structure, environment, and interdependence on the perceived usefulness of management accounting systems. Accounting Review, 61(1), 16-35.

Chong, V.K., \& Chong, K.M. (1997). Strategic choices, environmental uncertainty and SBU performance: A note on the intervening role of management accounting systems. Accounting and Business Research, 27(4), 268-276. http://dx.doi.org/10.1080/00014788.1997.9729553

Chuan, S.H., \& Lin, H.N. (2017). Performance implications of information-value offering in e-service systems: Examining the resource-based perspective and innovation strategy. Journal of Strategic Information Systems, 26(1), 2238, http://dx. doi.org/10.1016/j.jsis.2016.09.001

Clemons, E.K., \& Row, M.C. (1991). Sustaining IT advantage: The role of structural differences. MIS Quarterly, 15(3), 275-292. http://dx.doi.org/ $10.2307 / 249639$

Cooper, D.R., \& Emory, C.W. (1995). Business research methods. Chicago, IL: Richard D. Irwin. Inc.

Davis, G.F., \& Adam Cobb, J. (2010). Resource dependence theory: Past and future. In C.B., Schoonhoven \& F. Dobbin (Eds.), Stanford's Organization Theory Renaissance, 1970-2000 (pp. 21-42). UK: Emerald Group Publishing Limited.

Dorweiler, V.P., \& Yakhou, M. (2005). Scorecard for academic administration performance on the campus. Managerial Auditing Journal, 20(2), 138-144. http://dx.doi.org/10.1108/02686900510574557

Erhemjamts, O., Li, Q., \& Venkateswaran, A. (2013). Corporate social responsibility and its impact on firms' investment policy, organizational structure, and performance. Journal of Business Ethics, 118(2), 395-412. http://dx.doi. org/10.1007/s10551-012-1594-x 
Evangelista, R., Sandven, T., Sirilli, G., \& Smith, K. (1998). Measuring innovation in European industry. International Journal of the Economics of Business, 5(3), 311-333. http:/ / dx.doi.org/10.1080/13571519884413

Fornell, C., \& Larcker, D.F. (1981). Structural equation models with unobservable variables and measurement error: Algebra and statistics. Journal of Marketing Research, 18(3), 382-388. https:/ / dx.doi.org/ 10.2307/3150980

Galbreath, J., \& Galvin, P. (2008). Firm factors, industry structure and performance variation: New empirical evidence to a classic debate. Journal of Business Research, 61(2), 109-117. http://dx.doi.org/10.1016/j. jbusres.2007.06.009

Gao, H., Hsu, P.H., \& Li, K. (2018). Innovation strategy of private firms. Journal of Financial and Quantitative Analysis, 53(1), 1-32. http://dx.doi. org/10.1017/S0022109017001119

Gerloff, E.A., Muir, N.K., \& Bodensteiner, W.D. (1991). Three components of perceived environmental uncertainty: An exploratory analysis of the effects of aggregation. Journal of Management, 17(4), 749-768. http:/ / dx.doi. org/10.1177/014920639101700408

Gordon, L.A., \& Narayanan, V.K. (1984). Management accounting systems, perceived environment uncertainty and organization structure: An empirical investigation. Accounting, Organizations and Society, 9(1), 33-47. http:/ / dx.doi.org/10.1016/0361-3682(84)90028-X

Hair, J.F., Sarstedt, M., Hopkins, L., \& Kuppelwieser, V.G. (2014). Partial least squares structural equation modeling (PLS-SEM): An emerging tool in business research. European Business Review, 26(2), 106-121. http://dx.doi. org/10.1108/EBR-10-2013-0128

Hamel, G. (1999). Bringing silicon valley inside. Harvard Business Review, 77(5), 70-84.

Harash, E., Al-Timimi, S., \& Alsaadi, J. (2014). The influence of finance on performance of small and medium enterprises (SMES). International Journal of Engineering and Innovative Technology (IJEIT), 4(3), 161-167.

Hitt, M.A., Ireland, R.D., Camp, S.M., \& Sexton, D.L. (2001). Strategic entrepreneurship: Entrepreneurial strategies for wealth creation. Strategic Management Journal, 22(6-7), 479-491. http:/ / dx.doi.org/10.1002/smj.196

Kaplan, R.S. (2009). Conceptual foundations of the balanced scorecard. Handbook of Management Accounting Research, 3, 1253-1269. https://doi. org/10.1016/S1751-3243(07)03003-9

Kaplan, R.S., \& Norton, D.P. (1997). Why does business need a balanced scorecard? Journal of Cost Management, 11(1), 5-11.

Kaplan, R.S., \& Norton, D.P. (2001). The strategy-focused organization: How balanced scorecard companies thrive in the new business environment. Boston, MA: Harvard Business School Press.

Kettinger, W.J., Grover, V., Guha, S., \& Segars, A.H. (1994). Strategic information systems revisited: A study in sustainability and performance. MIS Quarterly, 18(1), 31-58. http://dx.doi.org/10.2307/249609 
Kuratko, D.F., Ireland, R.D., Covin, J.G., \& Hornsby, J.S. (2005). A model of middle-level managers' entrepreneurial behavior. Entrepreneurship Theory and Practice, 29(6), 699-716. http://dx.doi.org/10.1111/j.1540-6520.2005. 00104.x

Lichtenthaler, U., Hoegl, M., \& Muethel, M. (2011). Is your company ready for open innovation? MIT Sloan Management Review, 53(1), 45-48.

Lopez-Valeiras, E., Gonzalez-Sanchez, B., \& Gomez-Conde, J. (2016). The effects of the interactive use of management control systems on process and organizational innovation. Review of Managerial Science, 10(3), 487-510. http://dx.doi.org/10.1007/s11846-015-0165-9

Lussier, R.N., \& Pfeifer, S. (2001). A crossnational prediction model for business success. Journal of Small Business Management, 39(3), 228-239. http:// dx.doi.org/10.1111/0447-2778.00021

Mahmood, M.A., \& Mann, G.J. (1993). Measuring the organizational impact of information technology investment: an exploratory study. Journal of Management Information Systems, 10(1), 97-122. http:/ / dx.doi.org/10.1080/ 07421222.1993.11517992

Makhija, M. (2003). Comparing the resource-based and market-based views of the firm: Empirical evidence from Czech privatization. Strategic Management Journal, 24(5), 433-451. http:/ / dx.doi.org/10.1002/smj.304

Masa'deh, R. (2013). The impact of information technology infrastructure flexibility on firm performance: An empirical study of Jordanian public shareholding firms. Jordan Journal of Business Administration, 9(1), 204-224. http://dx.doi.org/10.12816/0002054

Masa'deh, R., Obeidat, B.Y., \& Tarhini, A. (2016). A Jordanian empirical study of the associations among transformational leadership, transactional leadership, knowledge sharing, job performance, and firm performance: A structural equation modelling approach. Journal of Management Development, 35(5), 681-705. http://dx.doi.org/10.1108/JMD-09-2015-0134

Masa'deh, R., Shannak, R., Maqableh, M., \& Tarhini, A. (2017). The impact of knowledge management on job performance in higher education: The case of the University of Jordan. Journal of Enterprise Information Management, 30(2), 244-262. http://dx.doi.org/10.1108/JEIM-09-2015-0087

Mazanai, M., \& Fatoki, O. (2011). The effectiveness of Business Development Services Providers (BDS) in improving access to debt finance by start-up SMEs in South Africa. International Journal of Economics and Finance, 3(4), 208-216. http://dx.doi.org/10.5539/ijef.v3n4p208

Mazzucato, M., \& O'Donovan, C. (2016). The BBC as market shaper and creator. In N., SethSmith, J. Mackay, \& D. Hind (Eds.), Rethinking the BBC: Public media in the 21st Century (pp. 101-105). London: Commonwealth Publishing.

Mazzucato, M., \& Penna, C. (2016). The Brazilian innovation system: A missionoriented policy proposal. Retrieved from https://www.cgee.org.br/thebrazilian-innovation-system 
McGahan, A.M., \& Porter, M.E. (1997). How much does industry matter, really? Strategic Management Journal, 18(special issue), 15-30.

Ministry of Industry. (2013). Facts and figures. Retrieved from http://www. kemenperin.go.id/majalah/11/facts-and-figures-industri-indonesia

Morrison, A., \& Teixeira, R. (2004). Small business performance: A tourism sector focus. Journal of Small Business and Enterprise Development, 11(2), 166173. http:/ / dx.doi.org/10.1108/14626000410537100

Nazaruddin, I. (1998). Pengaruh desentralisasi dan karakteristik informasi sistem akuntansi manajemen terhadap kinerja manajerial. Indonesia: Universitas Gadjah Mada.

Nguyen, T.T., Mia, L., Winata, L., \& Chong, V.K. (2017). Effect of transformational-leadership style and management control system on managerial performance. Journal of Business Research, 70(January), 202-213. http:/ / dx.doi.org/10.1016/j.jbusres.2016.08.018

Otley, D.T. (1980). The contingency theory of management accounting: Achievement and prognosis. Accounting, Organizations and Society, 5(4), 413-428. http://dx.doi.org/10.1016/0361-3682(80)90040-9

Rawashdeh, A., \& Al-namlah, L. (2017). Factors influencing electronic data interchange adoption among small and medium enterprises in Saudi Arabia. Asian Journal of Business and Accounting, 10(2), 253-280.

Roxas, B., Battisti, M., \& Deakins, D. (2014). Learning, innovation and firm performance: Knowledge management in small firms. Knowledge Management Research and Practice, 12(4), 443-453. http://dx.doi.org/10.1057/ kmrp.2012.66

Saunila, M. (2014). Innovation capability for SME success: Perspectives of financial and operational performance. Journal of Advances in Management Research, 11(2), 163-175. http:/ / dx.doi.org/10.1108/JAMR-11-20130063

Schmalensee, R. (1985). Do markets differ much? The American Economic Review, 75(3), 341-351.

Sprinkle, G.B. (2003). Perspectives on experimental research in managerial accounting. Accounting, Organizations and Society, 28(2-3), 287-318. http:// dx.doi.org/10.1016/S0361-3682(01)00058-7

Teece, D.J., Pisano, G., \& Shuen, A. (1997). Dynamic capabilities and strategic management. Strategic Management Journal 18(7), 509-533. http://dx.doi. org/10.1002/(SICI)1097-0266(199708)18:73.0.CO;2-Z

Terziovski, M. (2002). Achieving performance excellence through an integrated strategy of radical innovation and continuous improvement. Measuring Business Excellence, 6(2), 5-14. http://dx.doi.org/10.1108/ 13683040210431419

Thrikawala, S.S. (2011). Impact of strategic networks for the success of SMEs in Sri Lanka. World Journal of Social Sciences, 1(2), 108-119.

Ulusoy, G., Özgür, A., Bilgiç, T., Kaylan, A.R., \& Payzın, E. (2001). A study on technology management process: The parts and components suppliers in the Turkish automotive industry. Technology Management, 5(4), 245-260. 
Uyar, A., \& Kuzey, C. (2016). Contingent factors, extent of budget use and performance: A structural equation approach. Australian Accounting Review, 26(1), 91-106.

Venkatraman, N., \& Ramanujam, V. (1986). Measurement of business performance in strategy research: A comparison of approaches. Academy of Management Review, 11(4), 801-814. http://dx.doi.org/10.2307/258398

Verhoeven, B., \& Johnson, L.W. (2017). Business model innovation portfolio strategy for growth under product-market configurations. Journal of Business Models, 5(1), 35-50. http://dx.doi.org/10.5278/ojs.jbm.v5i1.1924 


\section{Appendices}

\section{Appendix A: Items of Measurement}

No. Name of Variable Indicator

$\begin{array}{ll}1 \text { Innovation Strategy } & \text { 1. Innovation } \\ & \text { 2. Technology }\end{array}$

2 Internal Business Process 1. Operations Management Process

Performance 2. Customer Management Process

3. Innovation Process

4. Regulatory and Social Processes
3 Management Accounting 1. Broadscope
Information System 2. Timeliness
3. Integration
4. Aggregate

4 Financial Performance 1. Cost Reduction

2. Improvement in Asset Utilisation.

3. Revenue Growth,

4. Improvement in Customer Value

\section{Appendix B: Direct Effect and Indirect Effect}
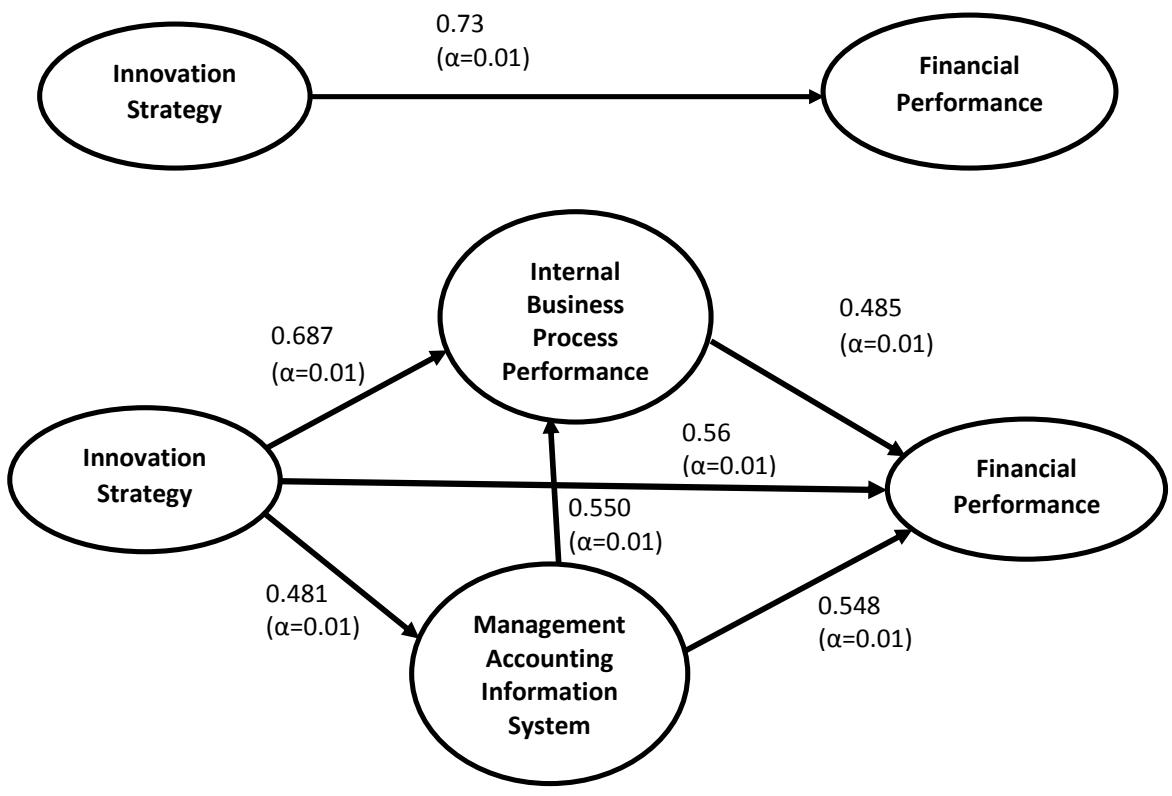